\title{
Article \\ Effect of Gaseous Chlorine Dioxide Treatment on the Quality Characteristics of Buckwheat-Based Composite Flour and Storage Stability of Fresh Noodles
}

\author{
Zhiyuan Cheng ${ }^{1}\left(\right.$, Xiaoping $\mathrm{Li}^{1}{ }^{1} * \mathbb{D}$, Jingwei $\mathrm{Hu}^{1}$, Xin Fan ${ }^{1}$, Xinzhong $\mathrm{Hu}^{1}$, Guiling $\mathrm{Wu}^{2}$ and Yanan Xing ${ }^{2}$ \\ 1 College of Food Engineering and Nutritional Science, Shaanxi Normal University, Xi'an 710062, China; \\ zhiyuanhi@126.com (Z.C.); $18392535049 @ 163 . c o m$ (J.H.); 15091478392@163.com (X.F.); \\ hxinzhong@126.com (X.H.) \\ 2 Cereal Industrial Technology Academy, Hebei Jinshahe Flour and Noodle Group/Hebei Cereal Food \\ Processing Technology Innovation Centre, Xingtai 054100, China; vmm1021@126.com (G.W.); \\ nanyaxing@126.com (Y.X.) \\ * Correspondence: xiaopingli@snnu.edu.cn; Tel.: +86-158-0929-8810
}

check for updates

Citation: Cheng, Z.; Li, X.; Hu, J.; Fan, X.; Hu, X.; Wu, G.; Xing, Y. Effect of Gaseous Chlorine Dioxide Treatment on the Quality Characteristics of Buckwheat-Based Composite Flour and Storage Stability of Fresh Noodles. Processes 2021, 9, 1522. https://doi.org/ $10.3390 /$ pr9091522

Academic Editor: Yonghui Li

Received: 1 August 2021

Accepted: 23 August 2021

Published: 27 August 2021

Publisher's Note: MDPI stays neutral with regard to jurisdictional claims in published maps and institutional affiliations.

Copyright: (c) 2021 by the authors. Licensee MDPI, Basel, Switzerland. This article is an open access article distributed under the terms and conditions of the Creative Commons Attribution (CC BY) license (https:/ / creativecommons.org/licenses/by/ $4.0 /)$.

\begin{abstract}
In this study, the effects of gaseous chlorine dioxide treatment on the physicochemical properties of buckwheat-based composited flour (buckwheat-wheat-gluten) and shelf-life of fresh buckwheat noodles (FBNs), as well as the textural qualities and sensory properties of noodles were investigated. Chlorine dioxide treatment significantly reduced the total plate count (TPC) and the total flavonoids content in the mixed flour $(p<0.05)$, but the whiteness, development time and stability time were all increased. During storage, the microbial growth and darkening rate of FBNs made from chlorine dioxide treated buckwheat-based composite flour (CDBF) were delayed significantly, slowing the deterioration and improving storage stability of buckwheat noodles. In addition, chlorine dioxide treatment had no apparent adverse effect on the cooking loss and sensory characteristics during noodle storage. This finding would provide a new concept for the production of "low bacterial buckwheat-based flour" and have important consequences for the application of gaseous chlorine dioxide in food industry.
\end{abstract}

Keywords: gaseous chlorine dioxide; buckwheat-based composited flour; fresh buckwheat noodle; shelf-life and quality characteristics

\section{Introduction}

Buckwheat is a kind of small coarse pseudocereal that belongs to the family Polygonaceae, which contains common buckwheat (Fagopyrum esculentum) and tartary buckwheat (Fagopyrum tataricum (L.) Gaertn). It is known as both medicine and food. Buckwheat is rich in resistant starch, dietary fiber, vitamins and minerals, which can prevent colon cancer, diabetes and obesity [1]. Due to its excellent nutritional value and unique protein composition, buckwheat is suitable for making gluten-free products, especially for celiac disease people [2]. Specifically, the Tartary buckwheat has more Vitamin B, crude fiber, minerals and flavonoids than those in common buckwheat [3], so it has received considerable attention as a functional food material in the food industry.

Noodle, the staple food in China, Korea and Japan, is widely enjoyed throughout the world because of its convenience and palatability [4]. In the past, because dried noodles and instant noodles were easy to preservation, many people chose to buy them. However, more and more consumers now prefer to the fresh noodles because of their good taste and nutritional quality [5]. To improve the nutrients and function of traditional wheat flour noodles, the production of buckwheat noodles is attracting a great deal of attention and buckwheat noodles have been consumed widely in most Asia countries and Italy. However, because of the lack of gluten in Tartary buckwheat, pure buckwheat noodles have poor processing and texture properties. To solve the problem, buckwheat noodles usually 
contain at least $20 \%$ wheat flour or other food additives to substitute gluten. In addition, because fresh buckwheat noodles have high water content and initial microorganisms, it has a shorter shelf-life when compared to the wheat noodles. Therefore, to better realize commercial production, some measures need to be taken to extend the shelf-life of fresh buckwheat noodles.

At present, many studies have been conducted to extend the shelf life of fresh noodles, through the application of chemical preservatives and physical preservation method (microwave, irradiation and modified packaging condition), that inhibited the microbial growth in noodle [6]. However, there methods have more or less some defects, such as consumers' doubts about the security of chemical preservatives, the unsatisfactory effect of one physical treatment, unsolved source problems with high microbial content in flour $[7,8]$. Therefore, alternative methods that can reduce or inhibit microbial growth in the flour and extend the shelf-life of noodles are still needed.

Chlorine dioxide, a strong and highly efficient oxidant, can be used in both aqueous and gaseous formulations to disinfect food and for food preservation $[9,10]$. It has been reported that chlorine dioxide can effectively inactivate insect, bacteria, fungi, viruses, spore and toxigenic molds. Stabilized $\mathrm{ClO}_{2}$ is legally allowed to be applied with surface treatment of fresh fruit and vegetables and aquatic product in China [11]. Early literature reports pointed out that chlorine dioxide has replaced agene as the more commonly used improver in wheat flour in the United States after extensive feeding experiments with animal and human being that had shown no clinical evidence of toxicity. [12,13]. In a recent literature, Liu et al. indicated that the aqueous chlorine dioxide treatment prolonged the shelf-life and improved the quality characteristics of fresh noodles [14]. When compared with aqueous form, the gaseous chlorine dioxide is attracting increasing attention due to its many advantages, including ease of mixing with air, powerful antimicrobial activity, low corrosivity to using equipment and low environmental impact $[9,10]$. Therefore, in recent years, chlorine dioxide gas has become one of the most effective disinfectants in the food industry [15]. In addition, it has been widely studied in the preservation of fresh fruits and vegetables, control of fungal contamination in stored grains and green coffee beans $[9,16]$. However, there are only a few studies on the effect of gaseous chlorine dioxide on the quality of buckwheat flour and the storage stability of fresh buckwheat noodles (FBNs). Therefore, the objective of this work was to obtain helpful information for the possible application of gaseous chlorine dioxide on tartary buckwheat flour and prolong the shelf-life of FBNs.

\section{Materials and Methods}

\subsection{Materials}

Tartary buckwheat flour was manufactured by Saixue Grain and Oil Industry and Trade Co., Ltd. (Dingbian, Shaanxi, China). The content of moisture and protein in which were $11.64 \%$ and $12.62 \%$ (on a dry basis). The commercial wheat flour $(12.10 \%$ moisture and $13.67 \%$ protein) was purchased from CR Vanguard supermarket. Salt was purchased from the local market. $\mathrm{ClO}_{2}$ powder was purchased from Zhangda Technology Development Co., Ltd., Tianjin, China. All chemical reagents used in this research was of analytical grade.

\subsection{Chlorine Dioxide Processing}

Before being treated, buckwheat flour (306 g), wheat flour (294 g) and wheat gluten $(60 \mathrm{~g})$ were uniformly mixed to form a mixed flour. The treatment of mixed flour with chlorine dioxide was carried out in a test chamber $\left(3 \mathrm{~m}^{3}\right)$ specially designed to produce chlorine dioxide. The gas is released through the reaction between water and solid $\mathrm{ClO}_{2}$ powder in the test chamber. A fan is placed in the chamber to spread the chlorine dioxide more quickly and evenly. Different treatments included the following combinations: $20 \mathrm{~g}$ of $\mathrm{ClO}_{2}$ powder and $1000 \mathrm{~mL}$ of sterile distilled water into a polypropylene container to generate concentrations of $76 \mathrm{ppm}$ after $30 \mathrm{~min}$ (low treatment); $40 \mathrm{~g}$ of $\mathrm{ClO}_{2}$ powder and $1000 \mathrm{~mL}$ of sterile distilled water to generate concentrations of $152 \mathrm{ppm}$ after $30 \mathrm{~min}$ 
(medium treatment); and $60 \mathrm{~g}$ of $\mathrm{ClO}_{2}$ powder and $1000 \mathrm{~mL}$ of sterile distilled water to generate concentrations of $232 \mathrm{ppm}$ after $30 \mathrm{~min}$ (high treatment). The mixed flour samples were exposed to the corresponding chlorine dioxide gas for $30 \mathrm{~min}$ to ensure a better treatment effect. After being treated, the flour was put into sterile plastic packaging bags and stored at room temperature until use.

\subsection{Determination of Total Flavonoid Content}

Total flavonoid contents in CDBF were determined using method described by Bai et al. [17] with a slight modification. The total flavonoid content was calculated based on a calibration curve of rutin standards $\left(y=17.246 x+0.028, R^{2}=0.9944\right)$ and expressed as $\mathrm{mg} / \mathrm{g}$ of dry weight.

\subsection{Color of Mixed Flour and Noodle Sheet}

The color values $\left(\mathrm{L}^{*}, \mathrm{a}^{*}\right.$ and $\left.\mathrm{b}^{*}\right)$ of the flour samples and fresh noodle sheets were measured using a chromameter (NS800, 3nh Technology Co., Ltd., Shenzhen, China). The noodle sheets were cut into pieces of approximately $5 \mathrm{~cm}$ in diameter and measured at 0 , 24,48 and $72 \mathrm{~h}$.

\subsection{Viscosity Analysis}

Pasting properties of CDBF were measured using a Rapid Viscosity Analyzer (RVA, model 4500, Newport Scientific, Warriewood, Australia) by the AACC 76-21 method. Suspensions were made by blending pure deionized water $(25 \mathrm{~g})$ and the flour samples $(3 \mathrm{~g})$, and the mixtures were uniformly mixed using the plastic paddle right before the RVA test, and then the tests were conducted in a programmed heating and cooling cycle.

\subsection{Swelling Power and Solubility}

The swelling power and solubility of flour were determined according to the method described by [18] with a slight modification. Flour sample $(0.5 \mathrm{~g})$ was transferred into centrifuge tube and add $15 \mathrm{~mL}$ of distilled water, then the mixture was placed in a water bath at $95{ }^{\circ} \mathrm{C}$ for $30 \mathrm{~min}$, with constant stirring. Then, the mixture was centrifugated at $3500 \mathrm{rpm}$ for $20 \mathrm{~min}$ after being cooled at room temperature. Eventually, the supernatant was decanted, and the tubes were weighted, the sediment weight was determined and the solubility (S, g/100 g) and swelling power (SP, g/100 g) were calculated as follows:

$$
\begin{aligned}
& \mathrm{S}(\mathrm{g} / 100)=\text { Dry supernatant weight }(\mathrm{g}) / \text { dry sample weight }(\mathrm{g}) \\
& \mathrm{SP}(\mathrm{g} / 100 \mathrm{~g})=\frac{\text { Sediment }(\mathrm{g}) \times 100}{\text { Dry sample weight }(\mathrm{g}) \times(100-\mathrm{S})}
\end{aligned}
$$

\subsection{Dough Rheological Characteristics}

Rheological characteristics of mixed flour samples were determined by Branbender farinograph (Model: JFZD; Dongfujiuheng Instrument Technology Co., Ltd., Beijing, China). Water absorption, dough development time, dough stability and degree of softening were automatic recorded by computer.

\subsection{Scanning Electron Microscopy (SEM) Observation of CDBF}

Tabletop scanning electron microscopy (Hitachi Consumer Marketing (China) Ltd., Shanghai, China) was used to obtain the micrographs of mixed flour. Before scanning mixed flour were coated with gold under vacuum.

\subsection{Preparation of Fresh Buckwheat Noodles}

Before the experiment, the lab and packing materials were sterilized using ultraviolet radiation. All instruments were disinfected with $75 \%$ alcohol. The buckwheat noodle formula consisted of $110 \mathrm{~g}$ of flour and $35 \mathrm{~mL}$ of distilled water, and $3 \mathrm{~g}$ of $\mathrm{NaCl}$. The noodle dough was formed with a Kitchen Aid Mixer (KM336, KENWOOD, Dongguan, 
China) with the following mixing parameters: medium speed mixing (the second gear) for $210 \mathrm{~s}$, high speed mixing (the third gear) for $60 \mathrm{~s}$ and low speed mixing (the first gear) for $150 \mathrm{~s}$, then the obtained dough crumbles were transferred into a sterilized plastic bag to rest for $20 \mathrm{~min}$. Subsequently, the rested crumbles passed through an experimental noodle machine (Ningbo Hantenite Machinery Co., Ltd., Ningbo, China) for 4 times folds, and the initial roller gap was set at $2.4 \mathrm{~mm}$ and then reduced from $2.0 \mathrm{~mm}$ to $1.5 \mathrm{~mm}$ to obtain dough sheets. The strands of the noodles were $2 \mathrm{~mm}$ in width and $1.5 \mathrm{~mm}$ in thickness. The fresh noodles were stored for $0,24,48$ and $72 \mathrm{~h}$ at $25^{\circ} \mathrm{C}$ for further research.

\subsection{Determination of TPC}

Total plate count (TPC) was examined according to the food microbiological examination standard of China (GB 4789.2-2016) with some modifications. The mixed flour and FBNs samples $(1.0 \mathrm{~g})$ were placed into $9 \mathrm{~mL}$ of $0.85 \%$ aseptic physiological saline (PA), and the mixture was shaken for $1 \mathrm{~min}$. Gradient dilutions were prepared using PA and $100 \mu \mathrm{L}$ of the appropriate dilutions were poured onto sterile plate count agar plates to determine the TPC. Then, the plates were incubated at $37^{\circ} \mathrm{C}$ for $48 \mathrm{~h}$, and the bacterial colonies were counted.

\subsection{Cooking Properties}

To determine the cooking loss, $25 \mathrm{~g}$ noodles were placed into $500 \mathrm{~mL}$ of boiling distilled water for $3 \mathrm{~min}$ until the hardcore of noodle strands disappeared. Next, the cooked noodles were rinsed in cold water for $1 \mathrm{~min}$. Then, the cooking water was collected into the volumetric flask $(500 \mathrm{~mL})$. An aliquot of $50 \mathrm{~mL}$ was added to a pre-weighted beaker and dried in an oven at $105^{\circ} \mathrm{C}$ till constant weight. The cooking loss was calculated as the percentage of the raw noodle.

cooking loss $(\%)=\frac{5 \times \text { Constant weight }}{\text { Weight of raw noodle } \times(1-\text { moisture content of rawnoodle })} \times 100 \%$

\subsection{Texture Properties of Cooked Noodles}

Textural properties of cooked noodles were measured using a TA-XT Plus Texture Analyzer (Stable Micro System, Surrey, UK) according to method described by Guo et al. [19] with some modifications. Briefly, fresh buckwheat noodles $(30 \mathrm{~g})$ were cooked in $500 \mathrm{~mL}$ of boiling distilled water until the optimal cooking time. The optimal test conditions with the $\mathrm{P} 36 / \mathrm{R}$ probe for tensile test as follows: strain, $75 \%$; pretest, test and post-test speed, $2 \mathrm{~mm} / \mathrm{s}, 1 \mathrm{~mm} / \mathrm{s}, 1 \mathrm{~mm} / \mathrm{s}$, respectively.

\subsection{Determination of $\mathrm{pH}$}

The noodle $\mathrm{pH}$ value was measured by a $\mathrm{pH}$ meter according to the method proposed by Guo et al. [8].

\subsection{Sensory Evaluation}

Sensory evaluations were performed by 10 well-trained team members. The 9-point hedonic rating scale was used to assess overall acceptability, with " 9 " means "very much", " 1 " means "very little" and " 5 " means "acceptable". These analyses were performed in a standard sensory room. The final result is obtained by averaging the values obtained by each people.

\subsection{Statistical Analysis}

All experimental data represent the mean of at least three replicates and standard deviation (SD). Significant differences were verified by one-way analysis of variance (ANOVA) using SPSS statistical software (25.0, SPSS Inc., Chicago, IL, USA). $p<0.05$ was considered statistically significant using Duncan's test. 


\section{Results and Discussion}

\subsection{Microbial and Physicochemical Changes in Mixed Flour}

\subsubsection{Microbial Count}

The most critical factor for the perishability of fresh noodles is the high level of initial microorganisms in the flour [4]. As a strong oxidant, chlorine dioxide is recognized by the Food and Agriculture Organization of the United Nations (FAO) as a highly effective and safe chemical disinfectant used for food preservation. Table 1 shows the total plate count (TPC) of chlorine dioxide treated and untreated buckwheat-based composite flour. There was a significant $(p<0.05)$ decrease in TPC of mixed flour with the increase of treating concentration. The initial TPC of flour without chlorine dioxide treatment was $4.35 \log _{10} \mathrm{CFU} / \mathrm{g}$. It decreased to $3.51 \log _{10} \mathrm{CFU} / \mathrm{g}$ when chlorine dioxide concentration increased to $232 \mathrm{ppm}$. This result shows that chlorine dioxide treatment can effectively reduce the initial bacterial quantity in buckwheat-based composite flour. Similar decreasing patterns were observed in carrots and tomatoes [20]. The decrease in TPC may be attributed to the damage effect of chlorine dioxide on microbial cells, thus inhibiting the microbial growth [10]. Furthermore, Guo et al. also pointed out that $\mathrm{ClO}_{2}$ could disrupt the protein synthesis in microorganisms [21]. Therefore, gaseous chlorine dioxide can be used to produce low-bacteria flour in the food industry.

Table 1. TPC and physiochemical of buckwheat-based composite flour as affected by chlorine dioxide treatment.

\begin{tabular}{|c|c|c|c|c|c|}
\hline \multirow{2}{*}{ Quality Parameters } & & \multicolumn{4}{|c|}{ Exposure Maximum Concentration } \\
\hline & & $0 \mathrm{ppm}$ & $76 \mathrm{ppm}$ & $152 \mathrm{ppm}$ & $232 \mathrm{ppm}$ \\
\hline TPC (Log CFU g-1) & & $4.35 \pm 0.07^{\mathrm{a}}$ & $4.01 \pm 0.07^{\mathrm{b}}$ & $3.63 \pm 0.07^{c}$ & $3.51 \pm 0.02^{c}$ \\
\hline \multirow[t]{3}{*}{ Color } & $L^{*}$ & $83.18 \pm 0.01^{\mathrm{c}}$ & $83.20 \pm 0.01^{c}$ & $83.52 \pm 0.01^{b}$ & $84.08 \pm 0.01^{\mathrm{a}}$ \\
\hline & $a^{*}$ & $-0.04 \pm 0.01^{\mathrm{c}}$ & $-0.05 \pm 0.01^{\mathrm{c}}$ & $0.41 \pm 0.01^{\mathrm{a}}$ & $0.36 \pm 0.00^{b}$ \\
\hline & $b^{*}$ & $12.85 \pm 0.01^{\mathrm{a}}$ & $11.32 \pm 0.01^{\mathrm{d}}$ & $11.69 \pm 0.01^{\mathrm{c}}$ & $11.74 \pm 0.01^{\mathrm{b}}$ \\
\hline \multirow[t]{5}{*}{ Farinograph Parameters } & Water Absorption (\%) & $60.2 \pm 0.2^{\mathrm{a}}$ & $60.3 \pm 0.02^{\mathrm{a}}$ & $58.3 \pm 0.01^{\mathrm{b}}$ & $58.3 \pm 0.0^{\mathrm{b}}$ \\
\hline & Development Time (min) & $6.95 \pm 0.07^{\mathrm{d}}$ & $7.4 \pm 0.15^{c}$ & $9.0 \pm 0.0^{\mathrm{b}}$ & $9.5 \pm 0.12^{\mathrm{a}}$ \\
\hline & Stability Time (min) & $8.20 \pm 0.00^{\mathrm{d}}$ & $8.45 \pm 0.07^{c}$ & $10.2 \pm 0.02^{b}$ & $10.8 \pm 0.04^{\mathrm{a}}$ \\
\hline & Degree of Softening (BU) & $97.50 \pm 2.12^{\mathrm{a}}$ & $87.5 \pm 0.71^{b}$ & $77.0 \pm 0.42^{c}$ & $75.0 \pm 0.32^{c}$ \\
\hline & $\begin{array}{l}\text { Farinograph Quality } \\
\text { Number (FQN) }\end{array}$ & $102.0 \pm 1.4^{\mathrm{d}}$ & $114.5 \pm 0.71^{\mathrm{c}}$ & $135.0 \pm 0.46^{\mathrm{b}}$ & $139.0 \pm 1.4^{\mathrm{a}}$ \\
\hline \multirow[t]{5}{*}{ RVA } & Peak Time (min) & $5.97 \pm 0.05^{\mathrm{a}}$ & $5.80 \pm 0.10^{\mathrm{ab}}$ & $5.67 \pm 0.00^{\mathrm{b}}$ & $5.64 \pm 0.05^{b}$ \\
\hline & Peak Visc. (cP) & $1169.00 \pm 2.83^{a}$ & $1138.00 \pm 1.41^{\mathrm{b}}$ & $1098.00 \pm 16.87^{c}$ & $1105.50 \pm 2.12^{\mathrm{c}}$ \\
\hline & Trough Visc. (cP) & $1069.50 \pm 2.12^{a}$ & $1039.50 \pm 3.54^{b}$ & $1022.50 \pm 17.68^{b}$ & $1015.50 \pm 3.54^{b}$ \\
\hline & Setback $(\mathrm{cP})$ & $809.50 \pm 12.02^{\mathrm{a}}$ & $761.00 \pm 12.73^{\mathrm{b}}$ & $718.00 \pm 24.04^{b}$ & $725.00 \pm 15.56^{b}$ \\
\hline & Final Visc. (cP) & $1879.00 \pm 9.90^{\mathrm{a}}$ & $1800.50 \pm 16.26^{b}$ & $1740.50 \pm 41.72^{b}$ & $1740.50 \pm 19.09^{b}$ \\
\hline Swelling Power (g/100 g) & & $7.95 \pm 0.02^{b}$ & $8.14 \pm 0.06^{\mathrm{ab}}$ & $8.49 \pm 0.58^{a b}$ & $8.77 \pm 0.03^{\mathrm{a}}$ \\
\hline Solubility $(\mathrm{g} / 100 \mathrm{~g})$ & & $13.39 \pm 0.70^{b}$ & $13.36 \pm 0.17^{b}$ & $14.75 \pm 0.88^{b}$ & $16.61 \pm 0.13^{\mathrm{a}}$ \\
\hline TFC (mg/g) & & $7.43 \pm 0.09^{a}$ & $6.94 \pm 0.00^{b}$ & $6.74 \pm 0.23^{b c}$ & $6.42 \pm 0.09^{c}$ \\
\hline
\end{tabular}

Note: The data in the table are the mean \pm SD. Means with different small letter superscripts within the same rows are significantly different at $p<0.05$.

\subsubsection{The Change of Total Flavonoids Content}

The total flavonoid content (TFC) in control and chlorine dioxide treated mixed flours are shown in Table 1. The control flour had the highest total flavonoids content $(7.43 \mathrm{mg} / \mathrm{g})$. The TFC in mixed flour decreased to $6.94,6.74$ and $6.42 \mathrm{mg} / \mathrm{g}$, respectively, when the exposure concentration was 76, 152 and $232 \mathrm{ppm}$. The decrease in total flavonoid content in buckwheat flour may be due to the loss of biological compounds caused by the strong oxidation of chlorine dioxide [17]. In this study, $86 \%$ total flavonoids remained after $232 \mathrm{ppm}$ chlorine dioxide treatment.

\subsubsection{Swelling Power and Solubility}

The swelling power (SP) and solubility (S) data of the buckwheat flour are presented in Table 1. Higher swelling power is usually required for the smooth surface and elastic texture of cooking noodles [4]. The SP and S of mixed flour with chlorine dioxide treatment showed higher values than the control. The increase of the swelling power of chlorine dioxide oxidized starch was due to the introduction of hydrophilic carboxyl groups [22]. Guo et al. suggested that carboxyl is the leading functional group produced in the oxidation process of starch [22]. The negative charges of carboxyl groups repel each other, causing 
starch granules swelling when heated in water. The solubility increases significantly with the increase of treating concentration. This may be due to the depolymerization and structural weakening of starch particles, and the solubility increases after oxidation [18].

\subsubsection{Color Analysis}

The color of flour is related to consumers' acceptance of the flour itself and its noodle products. Table 1 presents the color parameters in chlorine dioxide treated and untreated mixed flour. In this study, after chlorine dioxide treatment, the $\mathrm{L}^{*}$ value of mixed flour increased. In contrast, the $b^{*}$ value decreased significantly, indicating the treated flour appeared brighter and less yellow than the control. This result could be explained by the fact that chlorine dioxide can break down the natural yellow compounds (carotenoid and flavone) found in flour. This is consistent with the decrease in total flavonoids content observed in flour. In general, the color of CDBF is more visually acceptable and commercially valuable than untreated flour.

\subsubsection{Pasting Properties}

Pasting parameters of chlorine dioxide treated buckwheat-based composite flours are shown in Table 1, and RVA pasting curves are presented in Figure 1. According to Figure 1, it can be seen that with the concentration increasing of chlorine dioxide, the pasting temperature of the mixed flour decreased slightly, indicating that the concentration of the treatment used in this study did not inhibit the water absorption of the flour [23]. The trough viscosity $(1069.50 \pm 2.12$ to $1015.50 \pm 3.54)$ and final viscosity $(1879.00 \pm 9.90$ to $1740.50 \pm 19.09$ ) decreased significantly with the increase of the treatment concentration. The peak viscosity (from $1169.00 \pm 2.83$ to $1098.00 \pm 16.87$ ) decreased when the treating concentration increased from 0 to $152 \mathrm{ppm}$, however, in which a small increase of peak viscosity (from $1098.00 \pm 16.87$ to $1105.50 \pm 2.12$ ) was observed when the treatment concentration increased from 152 to $232 \mathrm{ppm}$. The peak viscosity of the $0-152$ ppm samples may be due to the oxidation of chlorine dioxide, which caused partial glycosidic bond cleavage, and in turn the decrease of starch molecular weight. Finally, the partially degraded starch could not maintain its particle integrity and was not resistant to shear, resulting in noodle viscosity decrease [24]. However, when treating concentration increase to $232 \mathrm{ppm}$, the increase of peak viscosity of samples may be caused by excessive oxidation which promoted a large amount of protein polymerization [25]. In addition, after chlorine dioxide treatment, the setback value of flour showed a decreased trend first (152 ppm) and then increased (232 ppm), indicating that excessive oxidation treatment would lead to easy retrogradation of starch. These results showed that treatment of flour with appropriate concentration of chlorine dioxide will be helpful to improve the gelatinization property of mixed flour.

\subsubsection{Farinograph Properties Analysis}

The farinograph indices of the mixed flour treated with different chlorine dioxide concentrations are presented in Table 1. After chlorine dioxide treatment, the water absorption of mixed flour decreased slightly with increasing treating concentration. However, the development time, stability time and farinograph quality number (FQN) of dough were significantly increased by chlorine dioxide treatment, indicating that the treated flours would form a stronger dough structure than un-treated flour. This may be due to the aggregation of proteins and the combination of proteins and starches that contributed to forming a stronger gluten network. The oxidation of chlorine dioxide can lead to cross-linking between proteins, thus increasing the strength of the dough [16]. In addition, Table 1 also showed that chlorine dioxide treatment decreased the degree of softening of the flour. The degree of softening suggests the rate of structural damage of the dough during the stirring process and it is inversely proportional to the strength of gluten. The lower the degree of softening, the easier the dough is to process. Present results indicated that chlorine dioxide treatment could enhance the processing property of mixed flour, which agrees with an early research that shows the effects of chlorine dioxide on the baking qualities of flour [26]. 


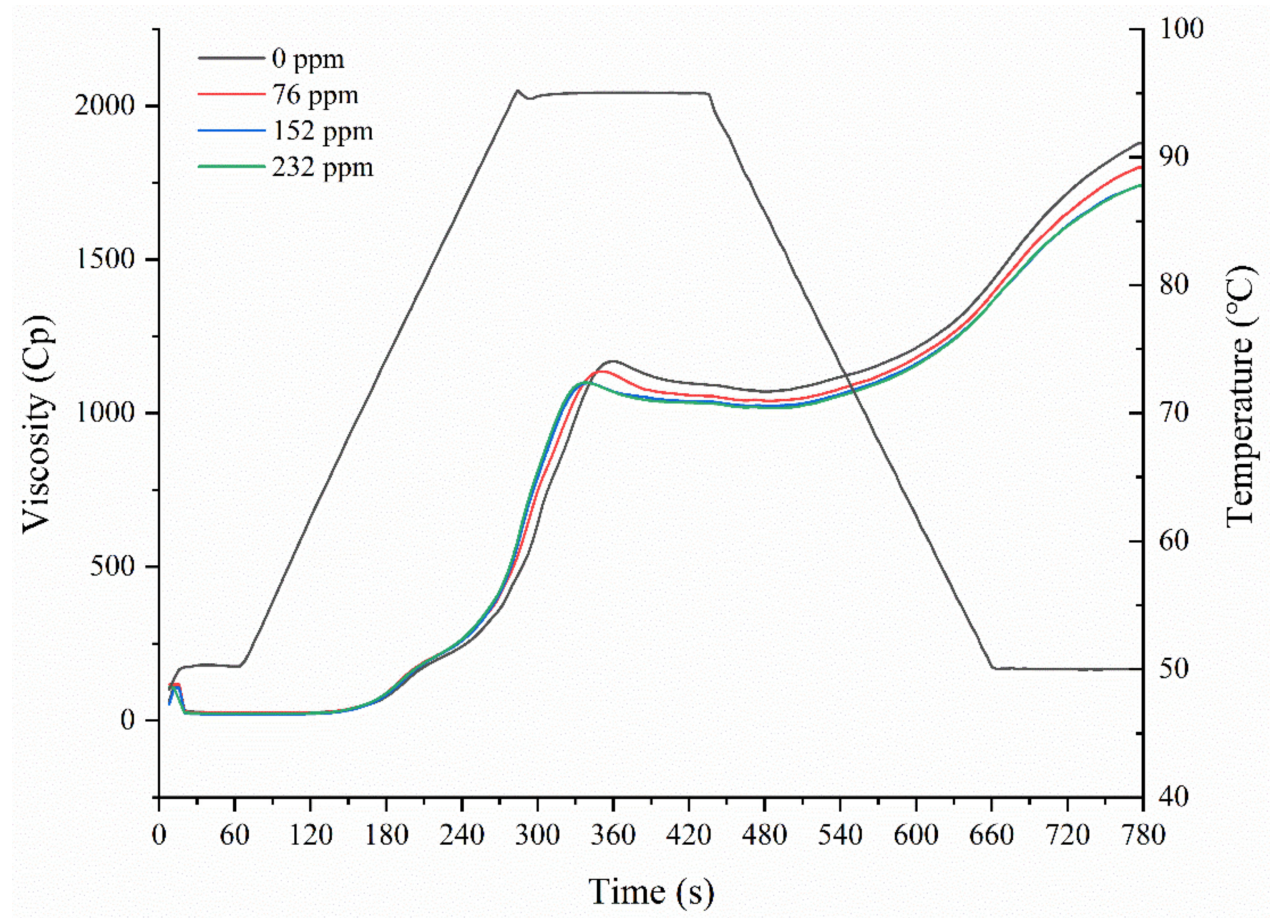

Figure 1. RVA pasting curves of buckwheat-based composite flour treated by gas chlorine dioxide at different concentrations.

\subsubsection{Microstructure of Mixed Buckwheat Flour}

Microstructures of the mixed buckwheat flour were examined by tabletop SEM and presented in Figure 2. At least three types of particle morphology including big, smooth and elliptical particle, aggregation of small particle and disperse tiny particles with different shapes and sizes could be observed in the control sample, which might be starch granules (big and smooth), buckwheat flour (aggregation of the small particle) and the protein bodies or fragments of protein matrix (disperse small particle). In addition, the disperse small particles might also contain fiber components and minerals [27]. After chlorine dioxide treatment, the disperse small particles in the mixed flour gradually decreased and the aggregation of small particle increased. In addition, it can be seen that surface of some starch granules emerged with spots and cracks. The effect of chlorine dioxide treatment on the morphology of flour particles may be caused by the oxidation of sulfhydryl and hydroxyl groups to form disulfide bonds and carboxyl groups [28]. In the early study, chlorine dioxide was used as the improver of wheat flour in the United States, indicating that it can increase the disulfide bonds of wheat flour. In the previous literature, Guo et al. found that the basic morphology of oxidized corn starch granules prepared by using chlorine dioxide as oxidant was not destroyed completely [22], but chlorine dioxide can penetrate into starch granules and cause damage on the surface and inside of starch granules.

\subsection{Microbial and Physicochemical Changes in FBNs \\ 3.2.1. Microbial Growth}

Changes of TPC in FBNs during storage were presented in Figure 3A. The TPC value of $10^{6} \mathrm{CFU} / \mathrm{g}$ in fresh noodles was considered as the cut-off point whether spoiled or unspoiled. Therefore, when TPC exceeds $1 \times 10^{6} \mathrm{CFU} / \mathrm{g}$, the detection of microbial quantity is terminated. FBNs made from CDBF exhibited lower initial TPC at $0 \mathrm{~h}$, which might be due to the low TPC in raw materials. During storage, the TPC of the control group increased rapidly and TPC exceeded $10^{6} \mathrm{CFU} / \mathrm{g}$ after $48 \mathrm{~h}$. With the increase of chlorine dioxide concentration, microbial growth of noodles made from CDBF was inhibited gradually. Moreover, the TPC of noodles made from flours treated with high 
concentration (232 ppm) of chlorine dioxide was still less than $10^{6} \mathrm{CFU} / \mathrm{g}$ after $96 \mathrm{~h}$ because of the lower initial microbial content. However, the total number of molds in buckwheat noodles exceeded the limit $(\geq 150)$. Therefore, $232 \mathrm{ppm}$ of chlorine dioxide can extend the shelf life of FBNs to $72 \mathrm{~h}$. The reduction of microorganisms in mixed flour is helpful for the prolong of the shelf life of FBNs. This phenomenon may be due to the damaging effect of chlorine dioxide on microbial cells, thereby delaying the growth of microbes. In the previous literature, Han et al. found gaseous chlorine dioxide can effectively control pests and fungal contamination in stored grain without reducing the viability of rice seed [16]. In recent years, gaseous chlorine dioxide has been used widely in the food industry as a fungicide [15]. Thus, we could conclude that gaseous chlorine dioxide treatment can be seen as an effective method to diminish the initial TPC level in FBNs by suppressing TPC count in flour and extending the shelf-life of buckwheat noodles.

\subsubsection{Color Changes in Noodle Sample}

Color is considered the primary determinant of the sales of noodle products, and it also reflects the changes in the quality of FBNs during storage. Changes in the $L^{*}$ value of noodles made from CDBF were showed in Figure 3B. Date was recorded at $24 \mathrm{~h}$ intervals during a period of $72 \mathrm{~h}$ storage. The initial $\mathrm{L}^{*}$ value of noodles made from CDBF increased significantly compared to that of the control. The initial $\mathrm{L}^{*}$ value of control (53.90) was lower than that of treated groups (54.92 at 76 ppm, 55.66 at 152 ppm and 55.85 at 232 ppm). This was mainly because chlorine dioxide treatment inhibits polyphenol oxidase activity (PPO) [29], thereby reducing the degree of enzymatic darkening. Chen et al. also reported that the treatment of fresh-cut asparagus lettuce with $\mathrm{ClO}_{2}$ aqueous solution could reduce its PPO activity [30]. With the extension of storage time, the $\mathrm{L}^{*}$ value of the control noodles decreased faster than that in the chlorine dioxide treated group and reduced to 48.05 (control group) at the end of $48 \mathrm{~h}$. In contrast, the $\mathrm{L}^{*}$ value of chlorine dioxide treated samples were 49.25 at 76 ppm, 50.80 at 152 ppm and 51.61 at 232 ppm. In addition, during the storage period, the high-concentration $(232 \mathrm{ppm})$ treatment delayed the decrease in $\mathrm{L}^{*}$ value more significantly. This result indicated that FBNs darkening could be inhibited by treating flour with chlorine dioxide.

(a)

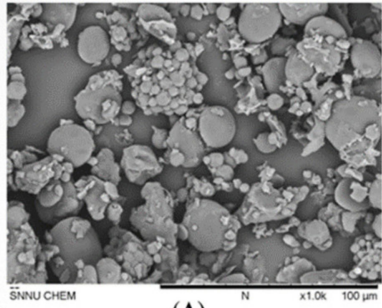

(A)

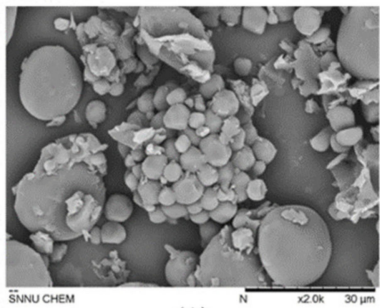

(A)

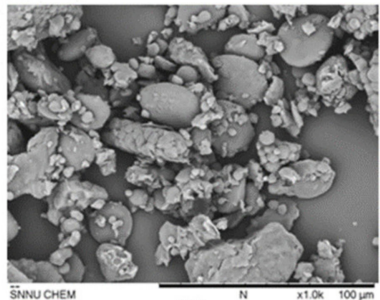

(B)

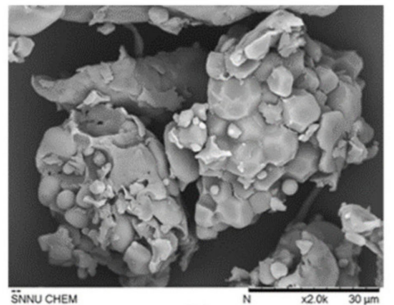

(B)

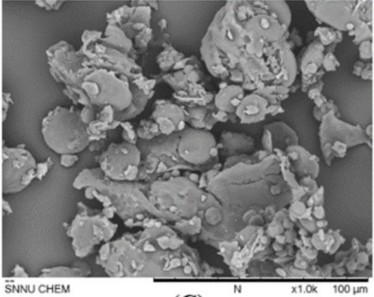

(C)

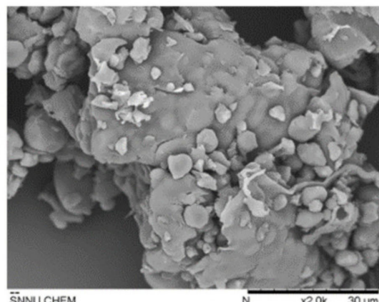

(C)

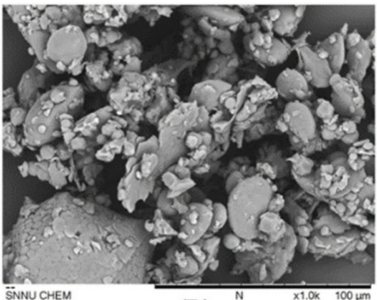

(D)

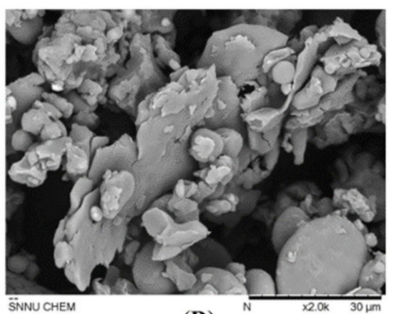

(D)

Figure 2. Microstructure ((a) 1000× magnification; (b) 2000× magnification) of buckwheat-based composite flour treated with chlorine dioxide at different treatment concentration: (A) 0 ppm; (B) 76 ppm; (C) 152 ppm; (D) 232 ppm. 


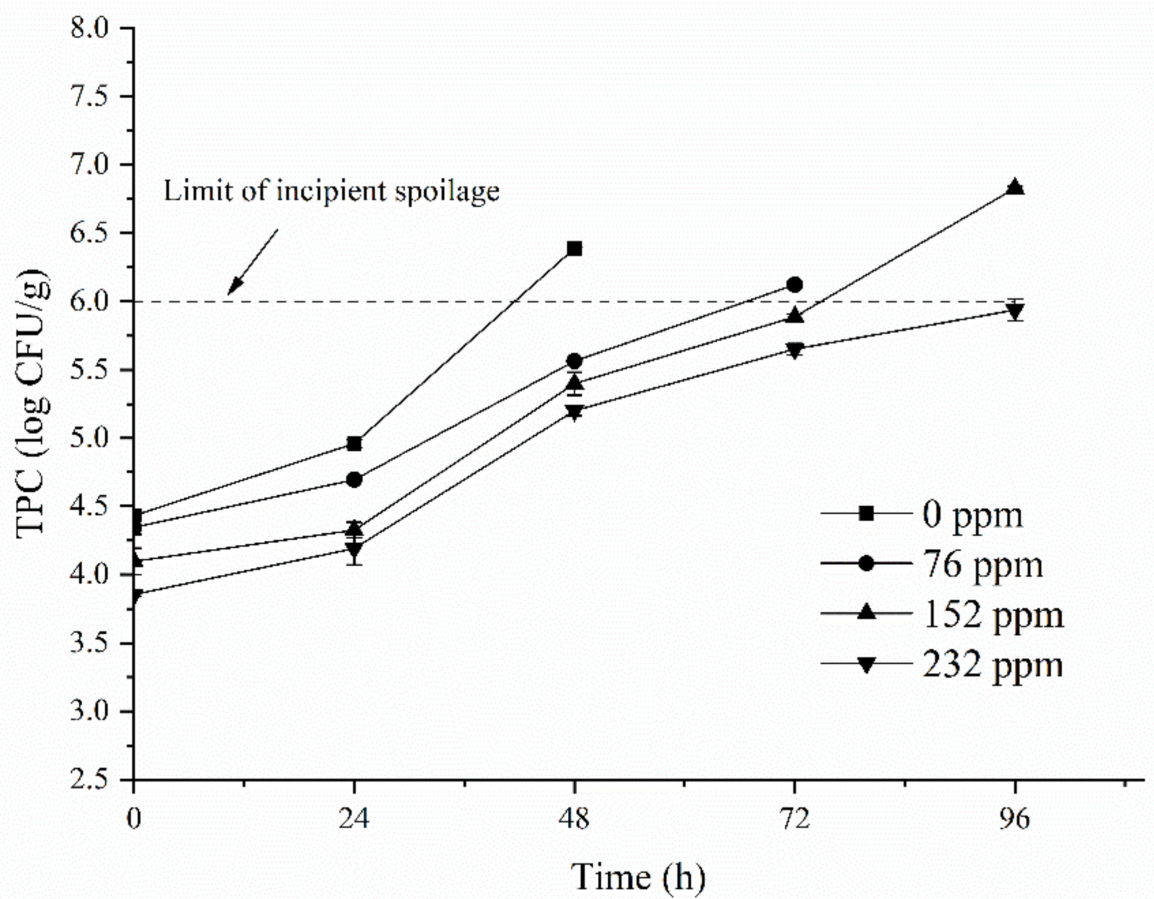

(A)

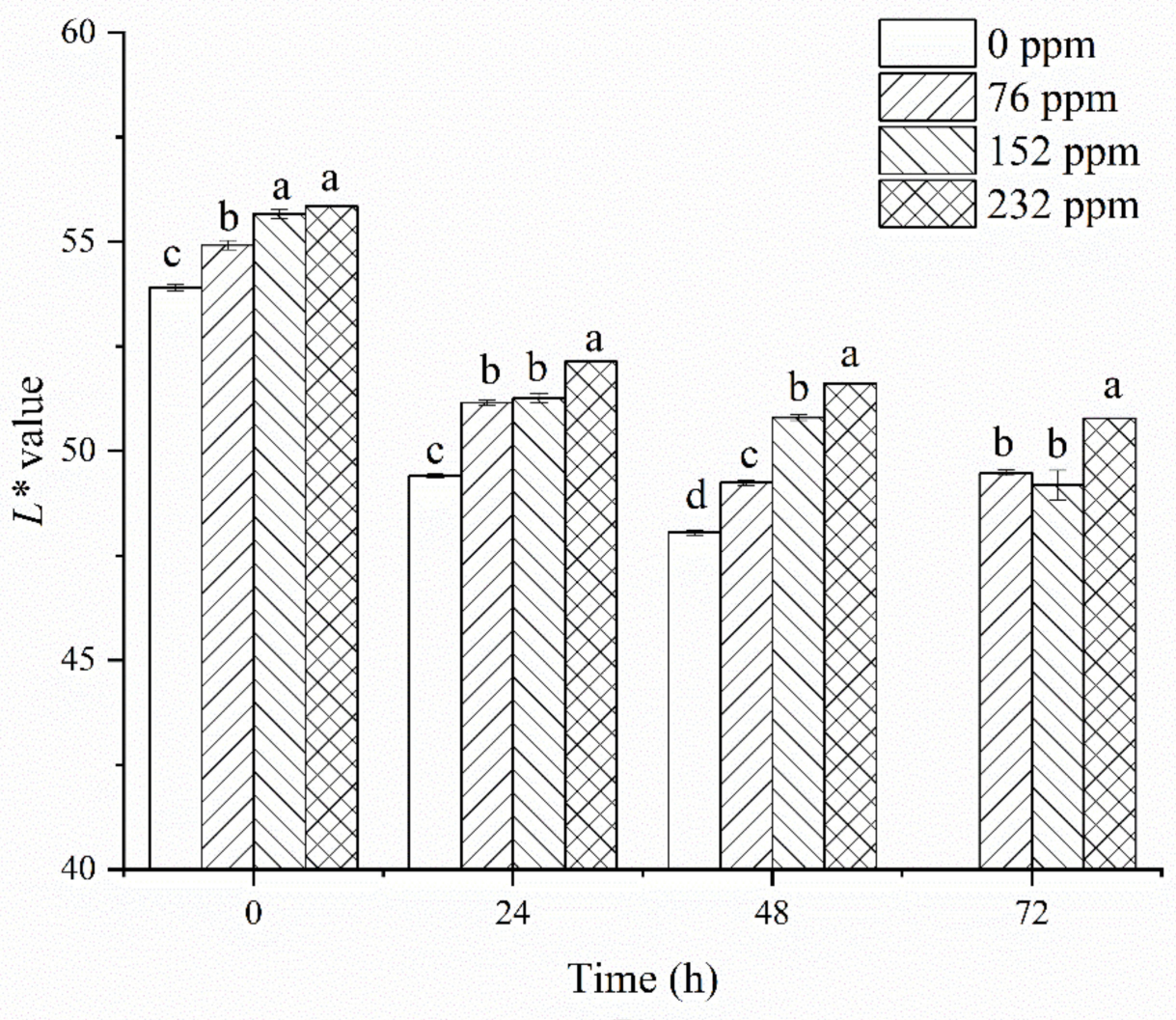

(B)

Figure 3. Cont. 


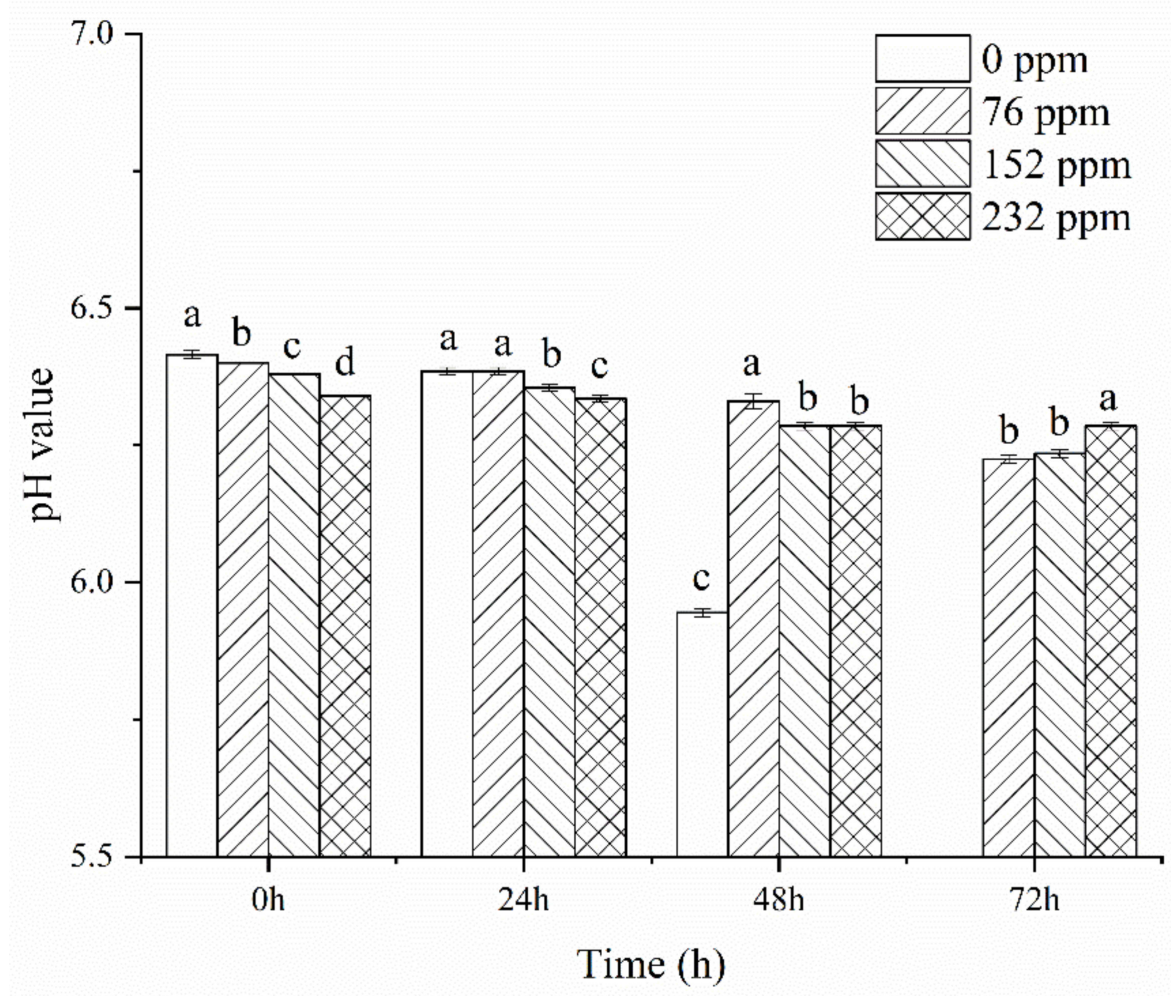

(C)

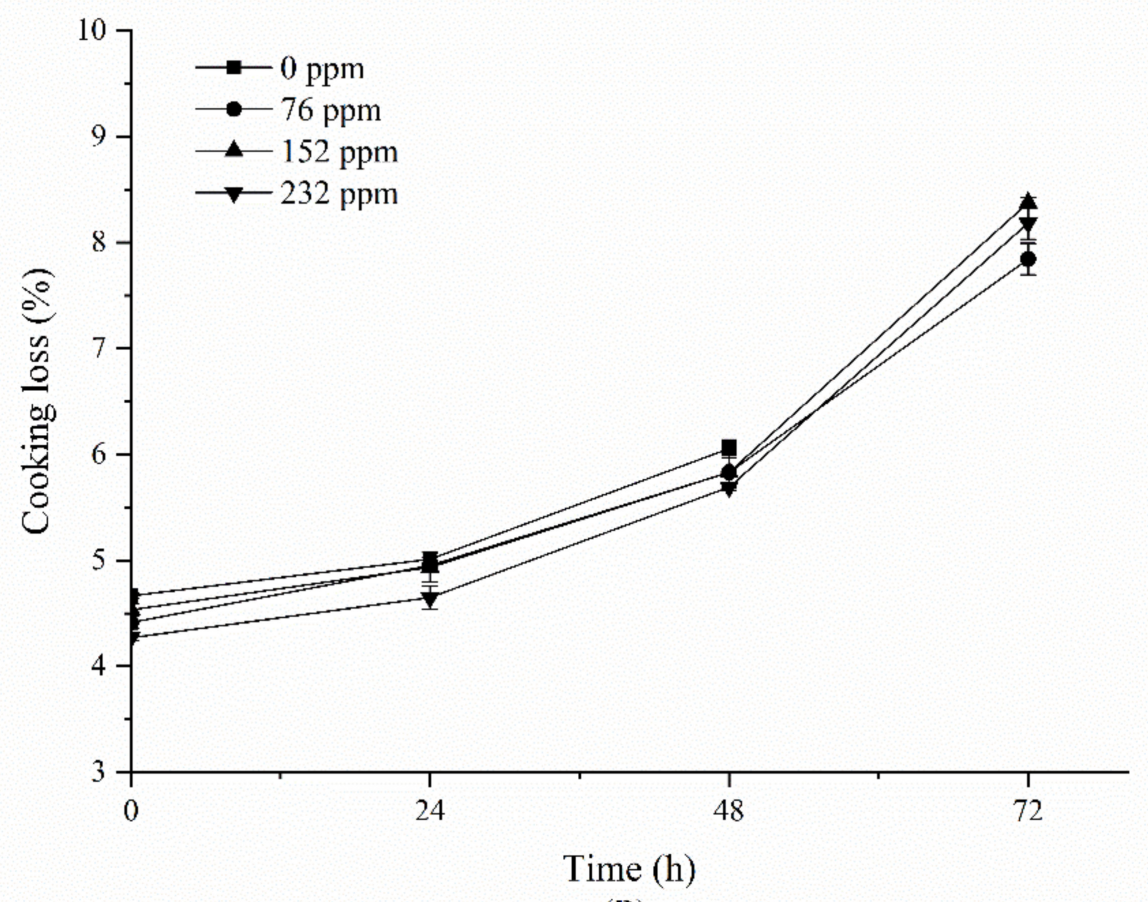

(D)

Figure 3. Effect of chlorine dioxide gas treatment on the microbial growth (A), $\mathrm{L}^{*}$ value (B), $\mathrm{pH}$ value (C) and cooking loss (D) in FBNs during storage. Different lowercase letters indicate significant differences at $p<0.05$.

\subsection{3. $\mathrm{pH}$ Changes in FBNs during Storage}

Figure $3 \mathrm{C}$ showed the $\mathrm{pH}$ changes in FBNs during storage. The initial $\mathrm{pH}$ values of chlorine dioxide treated samples were slightly lower compared to the control group. 
During storage, the $\mathrm{pH}$ value of all FBNs showed a continuous downward trend, and the $\mathrm{pH}$ value of the control group decreased faster than other treatment groups, especially from $24 \mathrm{~h}$ to $48 \mathrm{~h}$ This phenomenon was attributed to the growth of noodle bacteria at the suitable $\mathrm{pH}$ [31]. In carbohydrate-rich foods, microorganisms can use carbohydrates to produce acid, thereby reducing the $\mathrm{pH}$ value of the food. Therefore, it is common to observe a decrease in the $\mathrm{pH}$ of noodles during storage [32]. For FBNs made from CDBF, the lower initial $\mathrm{pH}$ values than the control group could be attributed to the oxidation effect of chlorine dioxide on the lipid and starch. Lyu et al. regarded the progress of lipid oxidation could be accelerated by chlorine dioxide [33], and as described in the microstructure of mixed flour, oxidization of carboxymethyl might lead to decrease of initial $\mathrm{pH}$ value of noodles. The reduction of $\mathrm{pH}$ in FBNs made from CDBF were slower than that in the control group due to the inhibition of microorganism growth. At the end of storage, the $\mathrm{pH}$ values of noodle made from $232 \mathrm{ppm}$ group were higher when compared to the other groups.

\subsubsection{The Cooking Loss of FBNs}

Cooking loss of FBNs during the storage was presented in Figure 3D. Cooking loss is defined as the amount of soluble matter in the cooking process of noodles. It indicates the extent of damage of noodles and their ability of structural maintenance during the cooking procedure [8]. As shown in Figure 3D, the cooking loss of FBNs was significantly reduced $(p<0.05)$ with the increase of chlorine dioxide concentration when the storage at $0 \mathrm{~d}$, which were 4.66 (control group), 4.41 (76 ppm), 4.53 (152 ppm) and 4.27 (232 ppm), respectively. In addition, the cooking loss of all noodles increased significantly with the extension of storage time. With the same storage time, the cooking loss of the untreated noodles was always higher than that of chlorine dioxide treated group. It is speculated that the oxidation effect of chlorine dioxide could strengthen the gluten network in FBNs (that can be confirm by farinograph properties data) through disulfide bond induced protein polymerization, which finally led to the cooking loss decrease of FBNs during storage. The starch granules were tightly packed by protein polymers during the cooking process, therefore, further reduced the cooking loss of the noodles. However, the growth and reproduction of microorganisms in noodles during storage may cause protein depolymerization and damage to the gluten network, resulting the increase the cooking loss of noodles [8].

\subsubsection{Texture Properties Analysis}

Changes in textural properties of FBNs during storage are shown in Table 2. The results showed that FBNs made from $\mathrm{CDBF}$ had higher hardness and springiness, and lower adhesiveness than the control. With storage time increasing, hardness and springiness of all the noodles decreased, and adhesiveness increased. However, compared with control noodles, the textural parameters of FBNs made from CDBF changed more slowly during the same storage period. Obviously, the texture deterioration of noodle was correlated with the growth rate of microorganisms, which further indicated that the proliferation and metabolism of microorganisms were the main cause of FBNs deterioration. The rapid proliferation of microorganisms in the control sample led to the quick deterioration of texture quality. This result is consistent with a previous study, that found that microbial activities caused the deterioration of texture characteristics of noodle products during storage [5]. 
Table 2. Effect of chlorine dioxide gas treatment on the changes of texture properties of FBNs during storage.

\begin{tabular}{|c|c|c|c|c|c|}
\hline \multirow{2}{*}{ Texture Profile } & \multirow{2}{*}{ Storage Time $/ \mathrm{h}$} & \multicolumn{4}{|c|}{ Exposure Maximum Concentration } \\
\hline & & 0 ppm & $76 \mathrm{ppm}$ & $152 \mathrm{ppm}$ & $232 \mathrm{ppm}$ \\
\hline \multirow{4}{*}{ Hardness(g) } & 0 & $3709.59 \pm 11.24^{b}$ & $3758.72 \pm 51.08^{b}$ & $3866.66 \pm 10.25^{\mathrm{a}}$ & $3888.29 \pm 48.16^{a}$ \\
\hline & 24 & $3493.44 \pm 20.77^{b}$ & $3706.77 \pm 70.88^{a}$ & $3648.60 \pm 40.50^{\mathrm{a}}$ & $3668.75 \pm 33.83^{a}$ \\
\hline & 48 & $3318.94 \pm 3.92^{b}$ & $3418.52 \pm 48.08^{b}$ & $3600.70 \pm 71.58^{a}$ & $3433.07 \pm 4.67^{b}$ \\
\hline & 72 & - & $3325.06 \pm 54.88^{b}$ & $3553.15 \pm 0.08^{\mathrm{a}}$ & $3546.55 \pm 9.42^{\mathrm{a}}$ \\
\hline \multirow{4}{*}{ Adhesiveness(g/s) } & 0 & $59.10 \pm 1.12^{\mathrm{a}}$ & $56.19 \pm 0.06^{b}$ & $55.61 \pm 0.61^{\mathrm{b}}$ & $57.16 \pm 0.20^{b}$ \\
\hline & 24 & $77.00 \pm 0.63^{\mathrm{a}}$ & $59.07 \pm 0.69^{d}$ & $63.80 \pm 1.06^{\mathrm{c}}$ & $67.14 \pm 0.41^{b}$ \\
\hline & 48 & $77.29 \pm 0.50^{\mathrm{a}}$ & $71.06 \pm 0.59^{b}$ & $63.99 \pm 0.65^{c}$ & $70.04 \pm 0.72^{b}$ \\
\hline & 72 & - & $71.47 \pm 0.41^{\mathrm{a}}$ & $69.71 \pm 0.15^{b}$ & $72.01 \pm 0.67^{\mathrm{a}}$ \\
\hline \multirow{4}{*}{ Springiness } & 0 & $0.91 \pm 0.00^{b}$ & $0.92 \pm 0.00^{\mathrm{a}}$ & $0.92 \pm 0.00^{\mathrm{a}}$ & $0.92 \pm 0.00^{\mathrm{a}}$ \\
\hline & 24 & $0.90 \pm 0.01^{\mathrm{a}}$ & $0.91 \pm 0.00^{\mathrm{a}}$ & $0.90 \pm 0.00^{\mathrm{a}}$ & $0.91 \pm 0.01^{\mathrm{a}}$ \\
\hline & 48 & $0.85 \pm 0.01^{c}$ & $0.88 \pm 0.01^{b}$ & $0.90 \pm 0.01^{\mathrm{a}}$ & $0.90 \pm 0.00^{\mathrm{a}}$ \\
\hline & 72 & - & $0.84 \pm 0.01^{b}$ & $0.89 \pm 0.01^{\mathrm{a}}$ & $0.89 \pm 0.01^{\mathrm{a}}$ \\
\hline
\end{tabular}

Note: The data in the table are the mean \pm SD. Means with different small letter superscripts within the same rows are significantly different at $p<0.05$. '-' Not detected.

\subsubsection{Sensory Evaluation}

Figure 4 shows the change in sensory properties of uncooked buckwheat noodles in terms of overall acceptability during storage. No significant chlorine dioxide odor was detected in the noodle samples during the whole storage period. The overall acceptability score of the control group on the first day was 8.6, slightly higher than that of the treatment group. The growth of noodle microbes caused unacceptable changes in taste, smell, appearance and any combination of these factors, resulting in spoilage [5]. With the extension of storage time, the overall acceptability scores of all samples showed a downward trend. Specifically, the sensory score (overall acceptability) of the control noodles decreased rapidly during the storage, which is related to the results of TPC. The rapid growth of microorganisms in noodles would have an adverse effect on the flavor of noodles, thus affecting the sensory evaluation. When the overall acceptability score is below 5 , the product is defined as unacceptable. At the end of storage, the overall acceptability score of 76 ppm group was less than 5; however, the overall acceptability score of 232 was higher than 5 . The reason may be that the protection of brightness and the inhibition of microbial growth are more evident in the chlorine dioxide treatment at $232 \mathrm{ppm}$. The results showed that high concentration of chlorine dioxide could prolong the shelf-life of FBNs to $72 \mathrm{~h}$.

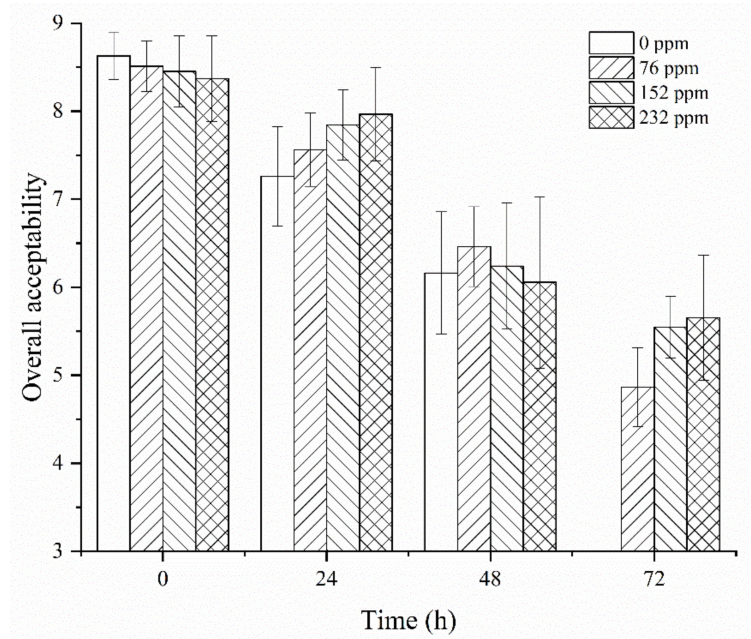

Figure 4. Overall acceptability of uncooked FBNs made from CDBF at different treatment concentration during storage. 


\section{Conclusions}

The effects of gaseous chlorine dioxide treatment on microorganism, physicochemical properties of CDBF and the quality of CDBN were evaluated in this study. It was found that chlorine dioxide treatment reduced the microorganisms and the total flavonoids content but caused increases of lightness and farinograph properties of the mixed buckwheat flour. In addition, fresh noodles made from CDBF have a longer shelf life and better quality characteristics during storage. The application of gaseous chlorine dioxide provides a new concept for the preservation of flour and fresh noodles. This study provides an effective raw material processing method for making fresh buckwheat noodles. To further improve the quality stability of buckwheat noodles during storage, more research is needed.

Author Contributions: Conceptualization, X.L.; methodology, X.L. and X.H.; software, J.H. and X.F.; investigation, Z.C. and J.H.; data curation, Z.C.; writing-original draft preparation, Z.C.; visualization, Z.C.; funding acquisition, G.W. and Y.X. All authors have read and agreed to the published version of the manuscript.

Funding: This research was supported by the National Natural Science Foundation of China (Grant No. 31470093), the Science and Technology Project of Xi'an City of China (Grant No. 20193046YF034NS034) and the Key Research and Development Programs of Shaanxi Province of China (Grant No. 2018TSCXL-NY-03-02).

Institutional Review Board Statement: Not applicable.

Informed Consent Statement: Not applicable.

Data Availability Statement: Data generated or analyzed during this study are included in this published article.

Conflicts of Interest: This study does not have any conflict of interest.

\section{References}

1. Ahmed, A.; Khalid, N.; Ahmad, A.; Abbasi, N.A.; Latif, M.S.Z.; Randhawa, M.A. Phytochemicals and biofunctional properties of buckwheat: A review. J. Agric. Sci. 2014, 152, 349-369. [CrossRef]

2. Giménez-Bastida, J.A.; Piskuła, M.; Zieliński, H. Recent advances in development of gluten-free buckwheat products. Trends Food Sci. Technol. 2015, 44, 58-65. [CrossRef]

3. Qin, P.Y.; Wang, Q.; Shan, F.; Hou, Z.H.; Ren, G.X. Nutritional composition and flavonoids content of flour from different buckwheat cultivars. Int. J. Food Sci. Technol. 2010, 45, 951-958. [CrossRef]

4. Li, M.; Zhu, K.X.; Wang, B.W.; Guo, X.N.; Peng, W.; Zhou, H.M. Evaluation the quality characteristics of wheat flour and shelf-life of fresh noodles as affected by ozone treatment. Food Chem. 2012, 135, 2163-2169. [CrossRef] [PubMed]

5. Li, M.; Ma, M.; Zhu, K.X.; Guo, X.N.; Zhou, H.M. Delineating the physico-chemical, structural, and water characteristic changes during the deterioration of fresh noodles: Understanding the deterioration mechanisms of fresh noodles. Food Chem. 2017, 216, 374-381. [CrossRef] [PubMed]

6. Li, M.; Zhu, K.X.; Guo, X.; Peng, W.; Zhou, H.M. Effect of water activity $(\mathrm{a}(\mathrm{w}))$ and irradiation on the shelf-life of fresh noodles. Innov. Food Sci. Emerg. 2011, 12, 526-530. [CrossRef]

7. Li, M.; Peng, J.; Zhu, K.X.; Guo, X.N.; Zhang, M.; Peng, W.; Zhou, H.M. Delineating the microbial and physical-chemical changes during storage of ozone treated wheat flour. Innov. Food Sci. Emerg. 2013, 20, 223-229. [CrossRef]

8. Guo, X.N.; Jiang, Y.; Xing, J.J.; Zhu, K.X. Effect of ozonated water on physicochemical, microbiological, and textural properties of semi-dried noodles. J. Food Process. Preserv. 2020, 44, e14404. [CrossRef]

9. Lee, H.; Ryu, J.H.; Kim, H. Antimicrobial activity of gaseous chlorine dioxide against Aspergillus flavus on green coffee beans. Food Microbiol. 2020, 86, 103308. [CrossRef]

10. Sun, X.; Baldwin, E.; Bai, J. Applications of gaseous chlorine dioxide on postharvest handling and storage of fruits and vegetablesA review. Food Control 2019, 95, 18-26. [CrossRef]

11. Sun, C.; Zhu, P.; Ji, J.; Sun, J.; Tang, L.; Pi, F.; Sun, X. Role of aqueous chlorine dioxide in controlling the growth of Fusarium graminearum and its application on contaminated wheat. LWT 2017, 84, 555-561. [CrossRef]

12. Meredith, P.; Sammons, H.G.; Frazer, A.C. Studies on the effects of treatment with chlorine dioxide on the properties of wheat flour. I.-The chemical composition of protein of treated flours. J. Sci. Food Agric. 1956, 7, 361-370. [CrossRef]

13. Moran, T.; Pace, J.; Mcdermott, E.E. Interaction of Chlorine Dioxide with Flour: Certain Chemical Aspects. Nature 1953, 171, 103-106. [CrossRef] [PubMed]

14. Liu, Z.G.; Xu, X.M.; Jin, Z.Y. Study on effect of chlorine dioxide and hydrogen peroxide on the preservation of wet raw noodles. Sci. Technol. Food Ind. 2008. [CrossRef] 
15. Park, S.H.; Kang, D.H. Influence of surface properties of produce and food contact surfaces on the efficacy of chlorine dioxide gas for the inactivation of foodborne pathogens. Food Control. 2017, 81, 88-95. [CrossRef]

16. Han, G.D.; Kwon, H.; Kim, B.H.; Kum, H.J.; Kwon, K.; Kim, W. Effect of gaseous chlorine dioxide treatment on the quality of rice and wheat grain. J. Stored Prod. Res. 2018, 76, 66-70. [CrossRef]

17. Bai, Y.P.; Guo, X.N.; Zhu, K.X.; Zhou, H.M. Shelf-life extension of semi-dried buckwheat noodles by the combination of aqueous ozone treatment and modified atmosphere packaging. Food Chem. 2017, 237, 553-560. [CrossRef]

18. Obadi, M.; Zhu, K.X.; Peng, W.; Sulieman, A.A.; Mohammed, K.; Zhou, H.M. Effects of ozone treatment on the physicochemical and functional properties of whole grain flour. J. Cereal Sci. 2018, 81, 127-132. [CrossRef]

19. Guo, X.N.; Wu, S.H.; Zhu, K.X. Effect of superheated steam treatment on quality characteristics of whole wheat flour and storage stability of semi-dried whole wheat noodle. Food Chem. 2020, 322, 126738. [CrossRef]

20. Bridges, D.F.; Rane, B.; Wu, V.C.H. The effectiveness of closed-circulation gaseous chlorine dioxide or ozone treatment against bacterial pathogens on produce. Food Control 2018, 91, 261-267. [CrossRef]

21. Guo, Q.; Wu, B.; Peng, X.Y.; Wang, J.D.; Li, Q.P.; Jin, J.; Ha, Y.M. Effects of chlorine dioxide treatment on respiration rate and ethylene synthesis of postharvest tomato fruit. Postharvest Biol. Technol. 2014, 93, 9-14. [CrossRef]

22. Guo, J.T.; Huang, Y.C.; Zhang, J.; Yin, J.W. Preparation of Oxidized Starch Using Environment Friendly Chlorine Dioxide as Oxidant. Int. J. Food Eng. 2014, 10, 243-249. [CrossRef]

23. Li, M.; Sun, Q.J.; Zhu, K.X. Delineating the quality and component changes of whole-wheat flour and storage stability of fresh noodles induced by microwave treatment. LWT 2017, 84, 378-384. [CrossRef]

24. Sandhu, K.S.; Kaur, M.; Singh, N.; Lim, S.T. A comparison of native and oxidized normal and waxy corn starches: Physicochemical, thermal, morphological and pasting properties. LWT Food Sci Technol. 2008, 41, 1000-1010. [CrossRef]

25. Hu, Y.M.; Wang, L.J.; Zhu, H.; Li, Z.G. Superheated steam treatment improved flour qualities of wheat in suitable conditions. J. Food Process. Preserv. 2017, 41, 10. [CrossRef]

26. Ferrari, C.; Hutchinson, W.; Croze, B.; Mecham, D. Flour bleaching with chlorine dioxide. Cereal Chem. 1941, 18, 699.

27. Aguilera, Y.; Esteban, R.M.; Benitez, V.; Molla, E.; Martin-Cabrejas, M.A. Starch, Functional Properties, and Microstructural Characteristics in Chickpea and Lentil as Affected by Thermal Processing. J. Agric. Food Chem. 2009, 57, 10682-10688. [CrossRef]

28. Tharanathan, R.N. Starch-value addition by modification. Crit. Rev. Food Sci. Nutr. 2005, 45, 371-384. [CrossRef] [PubMed]

29. Chen, S.J.; Wang, H.O.; Wang, R.R.; Fu, Q.Q.; Zhang, W. Effect of gaseous chlorine dioxide $\left(\mathrm{ClO}_{2}\right)$ with different concentrations and numbers of treatments on controlling berry decay and rachis browning of table grape. J. Food Process. Preserv. 2018, 42 , e13662. [CrossRef]

30. Chen, Z.; Zhu, C.H.; Zhang, Y.; Niu, D.B.; Du, J.H. Effects of aqueous chlorine dioxide treatment on enzymatic browning and shelf-life of fresh-cut asparagus lettuce (Lactuca sativa L.). Postharvest Biol. Technol. 2010, 58, 232-238. [CrossRef]

31. Bonafaccia, G.; Marocchini, M.; Kreft, I. Composition and technological properties of the, flour and bran from common and tartary buckwheat. Food Chem. 2003, 80, 9-15. [CrossRef]

32. Ghaffar, S.; As, A.; Abu Bakar, F.; Karim, R.; Saari, N. Microbial Growth, Sensory Characteristic and pH as Potential Spoilage Indicators of Chinese Yellow Wet Noodles from Commercial Processing Plants. Am. J. Appl. Sci. 2009, 6, 1059-1066. [CrossRef]

33. Lyu, F.; Zhao, Y.L.; Shen, K.J.; Zhou, X.X.; Zhang, J.Y.; Ding, Y.T. Using Pretreatment of Carbon Monoxide Combined with Chlorine Dioxide and Lactic Acid to Maintain Quality of Vacuum-Packaged Fresh Beef. J. Food Qual. 2018, 3158086. [CrossRef] 